\title{
МОВОЗНАВСТВО
}

\author{
УДК 81'22-11:164.02Августин Аврелій \\ DOI: http://dx.doi.org/10.30970/fpl.2020.133.3169
}

\section{ТЛУМАЧЕННЯ ЗНАКА В ТРАКТАТАХ СВ. АВГУСТИНА: ПОБІЧНІ МІРКУВАННЯ ЧИ ЦІЛІСНА ТЕОРІЯ?}

\author{
Надія Андрейчук
}

\author{
Львівський національний університет імені Івана Франка, \\ вул. Університетська, 1, м. Львів, Україна, 79000 \\ nadiya.andreychuk@lnu.edu.ua
}

\begin{abstract}
У статті розглянуто тлумачення мовного знака в трактатах середньовічного філософа Августина Аврелія "Про діалектику”, "Про вчителя" та "Про Християнську доктрину”. На матеріалі текстів латинських оригіналів та їхніх перекладів англійською мовою 3'ясовано вектор його семіотичних пошуків, спрямований на встановлення зв'язку речей, знаків та знання. Оцінено вклад Августина у становлення семіотики як науки та обгрунтовано переконання, що науковий дискурс Августина Аврелія про знаки становить цілісну семіотичну теорію, яка була створена для з'ясування низки аспектів його Християнської доктрини, і яка була першою доктриною знаків, що визначила розвиток семіотики на багато століть уперед.
\end{abstract}

Ключові слова: Августин Аврелій, знак, мовний знак, мовлення, знання.

$<\ldots>$ What we find in Augustine is a man who is a philosopher" in the original, etymological sense, a "lover of wisdom," one who is searching for it rather than one who writes as if he has found it and is now presenting it to us in systematic, argumentative form

Paul Vincent Spade

Вступ. Розвиток семіотичних ідей у період Середньовіччя невіддільний від розвитку філософської думки, основним джерелом якої стала Християнська релігія. Тенденція до зближення філософії і релігії формується вже в пізній античності. У IIIII ст. виникає перша християнська богословсько-філософська література і починається нова епоха в історії культури, яка пронизана духовністю Християнства [4, с. 129]. Містком між класичним та середньовічним світами й автором філософського обгрунтування Християнської доктрини справедливо вважається Августин Аврелій (354-430) християнський теолог і церковний діяч, єпископ міста Гіппон Регій ${ }^{1}$. Католицька та

1 Гіпон-Регій чи Гіпон Царський - місто в римській Африці на березі Гіппонської бухти Середземного моря, історичний попередник сучасної Аннаби (Алжир). Коли на чолі гіппонської єпископії стояв Августин Аврелій (останне століття існування Римської імперії), вона здобула великий авторитет і тут відбулося кілька церковних соборів, присвячених визначенню Біблійного канону. Саме тут були написані його основні праці. Августин помер під час облоги Гіппону вандалами.

Андрейчук Н., 2020 
православна церкви визнають його Святим (у православ 'ї він іменується Блаженним)1 . Зауважимо, що всі праці Августина написані латинською мовою. П. Содомора вважає, що саме завдяки Августинові тривалий період розвитку філософської думки отримав назву латинського, і саме Августин представляє третю вихідну позицію переходу від греки до латини після Порфирія і Боеція [8, с. 85].

Августина заслужено вважають одним із протагоністів європейської традиції, яка визначила розвиток Західного світу на багато століть уперед. Я. Пелікан американський патролог та історик християнства словацького походження - якось навіть висловив думку про те, що історія західної цивілізації- це лише серія приміток до Августина (цит. за [2, с. 164]). Ця думка дуже нагадує відомий вислів про роль Платона у філософії.

Аналіз останніх досліджень і публікацій. Спадщина Августина Аврелія привертає увагу дуже багатьох дослідників. Насамперед їі вивчають в контексті багатства Християнської традиції і передусім традиції Отців Церкви. Унікальна роль Августина в цьому контексті відображена навіть у тому, що Інститут патристики в Римі називається сьогодні “Августиніанум”. Більшість дослідників зосереджують увагу на його богословських поглядах, які, однак, невіддільні від філософських. Окрім низки вагомих концепцій у його релігійно-філософській системі ${ }^{2}$ Августин випрацював концепцію знака й жодне $з$ досліджень історії семіотичних учень не оминає його поглядів (див. історіографію семіотики у [25, §1.1.3]). Серед основних семіотиків, які зосереджують увагу на його тлумаченні знаків, назвемо К. Куйперса [23], Р. А. Маркуса [24], Б. Джексона [21], Ц. Тодорова ${ }^{3}$ [31], Г. Руефа [29], У. Еко [19], Д. С. Кларка [16], Дж Ділі [18], К. Скрипника [7] та ін. В Україні семіотичні погляди Августина в контексті навчання розглядав I. Кондратишин [2].

У пошуках основних положень теорії знаків Августина Аврелія дослідники зазвичай звертаються до трактатів "Про діалектику", “Про вчителя" та "Про Християнську доктрину”. Ц. Тодоров додає до цього списку трактат “Про трійцю” і наголошує, що погляди Августина не були незмінними, тому їх слід вивчати у динаміці, і що цінні думки, які мають стосунок до теми знаків, містяться в багатьох інших його працях $[9$, c. 27].

Результати дослідження та їхнє обгрунтування. Вперше Августин порушив питання знаків у написаному в молодості трактаті "Про діалектику” (приблизно

\footnotetext{
Значну частину відомостей про Августина отримано 3 автобіографічної “Сповіді” (Confessiones), яка була блискуче перекладена з латини українською мовою Юрієм Мушаком [6].

2 Сюди зараховують концепції, пов'язані з питаннями: Бог і світ, добро і зло, людина і душа, пізнання і воля, віра і розум, наука і мудрість, людська воля і Божа благодать, суспільство й історія та ін.

3 Книга Тодорова “Теорії символу” була написана французькою мовою в 1977 році. У першому розділі цієї книги він розглядає зародження західної семіотики і не оминає тлумачення знака у Августина. У 1982 р. Катерина Портер переклала цю книгу англійською мовою [31], а в 1998 році вона вийшла російською мовою в перекладі Бориса Нарумова [9].
} 
387 р.) $)^{1}$. У першому параграфі цього трактату він характеризує їі як науку про правильне міркування 3 використанням слів. П'ятий параграф трактату розпочинається 3 двох тверджень. Одне з них стало класичним визначенням знака: "Signum est quod et se ipsum sensui et praeter se aliquid animo ostendit (A sign is something which presents itself to the senses and something other than itself to the mind)" - знак $є$ щось, що виявляє себе відчуттям, а щось відмінне від себе - розумові. У цьому визначенні міститься чітка вказівка на двоїсту природу знака: він одночасно сприймається органами чуттів і розумом. Друге важливе твердження: “Verbum est uniuscuiusque rei signum, quod $a b$ audiente possit intellegi, a loquente prolatum ( $A$ word is the sign of some thing which can be understood by the hearer when pronounced by the speaker)" - слово є знаком певного предмета, який може зрозуміти слухач, коли воно вимовляється мовцем. Цим твердженням накреслюється зв'язок мовного знака з об'єктом означення (план означування) та зв'язок мовця і слухача (план комунікаціі); отже, вперше говориться про те, що мовний знак “працює” в процесі спілкування. Ц. Тодоров зазначає, що опис комунікативного параметру відсутній у стоїків, які створювали чисту теорію значення, $\mathrm{i}$ не так чітко представлений в Аристотеля, який враховував мовців, пишучи про “душевні стани", однак контекст комунікації залишав у тіні [9].

Далі Августин розглядає слово як знак і наголошує, що слово 'звучить' (sonat). Написане слово не $є$ словом, а лише знаком слова. Коли читач бачить слова, літери діють на розум, який їх озвучує. Тобто предметом написаного мовного знака (написаного слова) $є$ вимовлене слово, а останнє $є$ знаком предмета. Отож, уже перші положення знакової теорії Августина привертають увагу до дії знака на розум через дію на органи чуття. Через 15 століть Ч. Пірс, розглядаючи поняття семіозису, напише, що динамічна дія чи дія грубої, фізичної чи психічної, сили має місце між двома суб'єктами і є результатом дії між парами. Однак наголосить, що семіозис як дія знака передбачає взаємодію трьох суб'єктів: знаку, його об'єкту та інтерпретанти [27].

Августин виокремлює в природі мовного знака чотири складники: слово (verbum); те, що виражається (dicibile); вираження (dictio) й річ (res) (див. рис. 1).

Отож, dicibile міститься в розумі й відповідає грецькому lekton у тлумаченні стоїків. За свідченням Секста Емпірика, стоїки стверджували, що є три взаємопов'язані речі: означене, означник та референт. Вони першими термінологізували означник: “означником є звук, як-от, “Діон”” (цит. за [1, с. 148]). Означник в усій його матеріальності (вимовлене й почуте) виявляє означене: “Означеним же є сама річ, яка виявлена ним [= звуком] і яку ми осягаємо нашим розумом як таку, що співіснує [зі звуком], тоді як варвари ії не сприймають, хоч і чують звук” (визначення Секста Емпірика з трактату “Проти вчених”, цит за [1, с. 148]). Далі Секст пояснює, що з трьох складників два $\epsilon$ тілами, а саме звук і те, що трапляється - Діон/Діон, а третій є безтілесним, а саме означена річ і висловлюване/висловлене, для якого греки придумали назву лектон. Дж. Ділі вважає, що в розв'язанні проблеми співвідношення dictio i dicibile Августин

Для аналізу використано латинський текст із вже згадуваного сайту Augustinus Hipponensis [14] та англійський переклад, опублікований цифровою бібліотекою The Christian Classics Ethereal Library, яка вже розмістила в Інтернеті сотні книг Християнської класики. Стосовно тексту Августина On Christian Doctrine [30], то, на жаль, не вказано імені перекладача. 


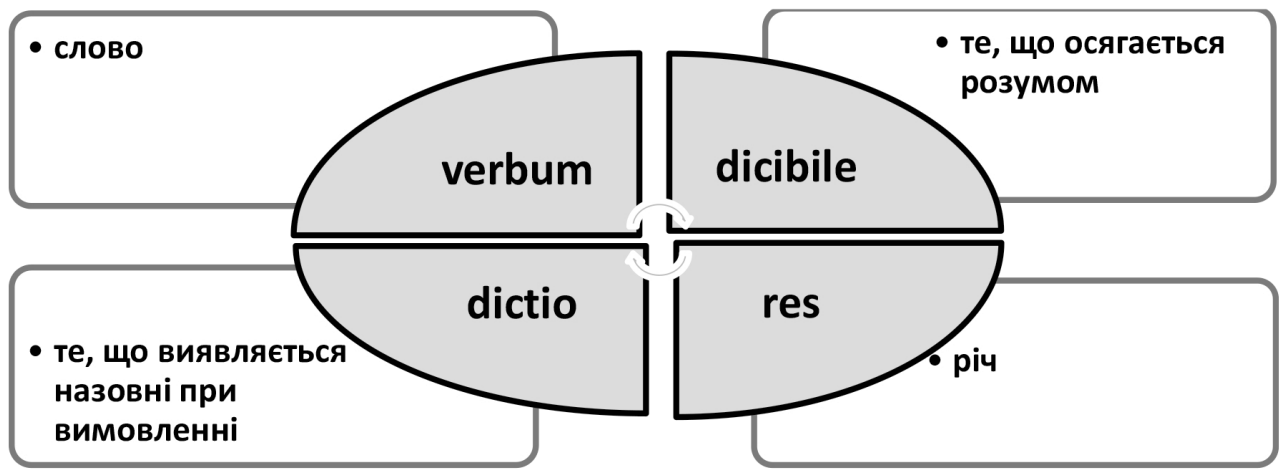

Рис. 1. Складники знака в Августина.

терпить поразку, бо чітко не встановлює відмінності між фізичним продукуванням певної дії, яка є причиною “буття” (але не означування), і тим випадком, коли причина буття й причина означування $є$ частиною одного процесу [18]. Не погоджуюся 3 цією критикою Ділі, оскільки в аналізі Августина мова йде про мовний знак, де фізичне продукування (звукове чи буквене) завжди є семіозисом, тобто процесом, в якому результат такого продукування $\epsilon$ для інтерпретатора знаком. Радше можна критично аналізувати той факт, що для означника Августин використовує два терміни: dictio i verbum. Це термінологічне подвоєння сам Августин пояснює так: 'Quod dixi 'verbum' et verbum est et 'verbum' significat (What I have called 'word' is both a word and signifies 'word')' - Те, що я назвав 'слово', є словом і воно означує 'слово'. Отож, verbum - це не те, що виявляється назовні голосом, а радше узагальнене представлення мовного знака, яке вже в XX ст. Ч. Пірс назве нерозривною єдністю репрезентамена (diction), інтерпретанти (dicibile) та об'єкта (res) (див. [28]). Міркування Пірса, які сьогодні визнаються засадничими в науці про знаки, $\epsilon$, фактично, поглибленням ідей Августина. У статті “Про природу знаків” (1873) Пірс пише: “Знак - це об’єкт, який заміщує інший у розумі... Перш за все, як і кожна річ, він повинен мати притаманні йому властивості, які дозволять вважати його знаком. Отож, надруковане слово $є$ чорним, має певну кількість літер, і ці літери мають певну форму. Ці властивості знака я називаю матеріальними. По-друге, знак повинен мати реальний зв'язок 3 річчю, яку він означує, щоб знак означував саме іiі, якою вона $\epsilon$, а не інакше. Я назву цю властивість знаків вказуванням. По-третє, щоб знак був знаком, він повинен розпізнаватися як знак, бо знак є знаком лише для того розуму, який розпізнає його як знак, $\mathrm{i}$, якщо знак не є знаком для жодного розуму, то це не знак. Його матеріальні властивості та його вказувальна функція повинні бути в розумі. Цей розум має встановлювати зв'язок з об'єктом, щоб забезпечити перехід від знака до речі” [28]. Очевидно, що опис “матеріального” та “вказувального” у Пірса співвідноситься 3 dictio i dicibile у Августина.

Через два роки після написання трактату “Про діалектику” в 389 році Августин написав діалог “Про вчителя”, дійовими особами якого є сам Августин і його син 
Адеодат ${ }^{1}$. На час написання діалогу синові виповнилось 16 років і невдовзі після цього він помер ${ }^{2}$. У цьому діалозі Августин продовжує розвивати теорію знаків і робить це в контексті передавання або отримання знань. У дисертації Ч. Конегана “Знаки, мова і знання в DE MAGISTRO Августина” (захищена у 2004 р.) стверджується, що це основна праця Августина, яка дає уявлення про його філософію мови [17, с. 2]. Цей трактат спрямований на пошук шляхів отримання знання. При цьому обраний підхід пов'язаний з мовою, оскільки отримання знання включає навчання, навчання включає навчальний процес, а навчальний процес включає розповідь чи демонстрацію чогось комусь. Розповідь - найочевидніша форма навчання, отож, Августин розпочинає розгляд отримання знання з роздумів про здатність мови передавати інформацію. Вже перше запитання Августина "Quid tibi videmur efficere velle cum loquimur? (What do you suppose is our purpose when we use words?)” - Що, на твою думку, є нашим наміром, коли ми говоримо? - впроваджує розуміння, що дія (efficere) мовлення (loqui) виконується 3 певним наміром (velle). В англійському перекладі оригіналу перекладач заміняє 'мовлення' на 'використання слів', хоча така заміна видається обгрунтованою з урахуванням подальшого тлумачення мовлення в трактаті. У термінах сучасної комунікативної лінгвістики ми б сказали, що імпліцитно в першому питанні закладено дві речі: 1) інтенційність мовлення (комунікативний аспект); 2) розуміння мови як засобу, здатного забезпечити успішність мовленнєвого акту (здійснення наміру). Відповідь на це питання: “... aut docere aut discere (...we want to let people know something, or we want to learn something)" - навчати або навчатися - визначає подальший вектор розгляду мовлення, а саме: чи мова насправді вчить $\mathrm{i}$, якщо так, то як вона це робить і наскільки успішно; що таке навчання з погляду вчителя і з погляду учня i, нарешті, що таке знання і як воно здобувається. Отож, ми говоримо, щоб навчати. Чи мова забезпечує досягнення цієї мети? Так, якщо прирівнювати навчання до передавання інформації загалом. Надзвичайно вагоме тлумачення процесів передавання знань, яке грунтується на засадах логіки, філософії прагматизму та семіотики, дав Пірс у статті “Як зробити наші думки зрозумілими” [26], однак саме Августин привернув увагу до знакової природи цих процесів.

У діалозі Августин дає декілька тлумачень мовлення. Початково він визначає його як вимовляння слів і наголошує, що слова використовуються для навчання (docendito teach) або нагадування (commemorandi - to call something to mind). Розглядається аргумент, що, якщо мовлення - це лише вимовляння слів, то спів теж є вимовлянням слів i, якщо хтось співає в самоті, то таке вимовляння слів не $€$ навчанням. Тому навчання потребує наміру навчити чогось, чого ми хочемо навчити, і когось, хто буде вчитися. Навчання також може здійснюватися через нагадування - commemoratio (reminding):

1 Для аналізу цього трактату використано латинський текст з сайту Sant' Agostino (Augustinus Hipponensis) [15] та англійський переклад шотландського священика та дослідника Біблії Джона Бурлея [12].

2 Перші десять розділів містять діалог Августина та його сина 3 питань, які стосуються природи знаків у контексті навчання, а заключні чотири розділи розкривають тлумачення істини в епістемології Августина. Питання, які ставить Адеодат, дуже глибокі, і йому належать заключні слова. Вважається, що він був обдарованим юнаком і був відданий батькові. 
"At ego puto esse quoddam genus docendi per commemorationem, magnum sane, quod in hac nostra sermocinatione res ipsa indicabit (And yet I think there is a kind of teaching, and a most important kind, which consists in reminding people of something"). Очевидно, що Августин розмежовує вчити (включає соттетоrare) і вчитися (включає recordari): “... nos discere cum recordamur nec docere iliumqui commemorat... (... we learn by remembering, or that he who reminds us of something really teaches us...") - <...> Ми навчаємося через пригадування, чи той, хто нагадує нам про щось, насправді навчає нас.... Отож, картина вчити/вчитися передбачає, що $\mathbf{x}$ нагадує, а $\mathbf{y}$ пригадує, а commemoratio, включає два процеси: нагадування іншим і пригадування для себе. Акт нагадування потребує активної ролі учня, який пригадує. Тут Августин закладає основи сучасних поглядів на: а) інтенціональність як здатність розумів та ментальних станів репрезентувати чи заміщати речі, властивості та стани справ. Сучасні філософи вважають, що різним ментальним станам, зокрема намірам, притаманна інтенціональність, зокрема, коли мовець вимовляє слова природної мови чи використовує символи формальної мови $з$ метою передавання іншим вмісту його ментальних станів, то ці артефакти $\epsilon$ “інтенціональними” [22] $]^{1}$ б) роль інтерпретатора в процесі семіозису: щось може бути знаком лише, коли хтось інтерпретує його як знак.

Друге розширене тлумачення мовлення в діалозі: “Qui enim loquitur, suae voluntatis signum foras dat per articulatum sonum (He who speaks gives by articulate sound an external sign of what he wants)" - Артикульоване мовлення $є$ зовнішнім знаком наміру мовця. Мовець продукує (forasdat) через артикульований звук (per articulatum sonum) знак (signum) його волі (suae voluntatis). Вимовляючи слова, ми означуємо думки, отож, мовлення - це вимовлені звуки у формі слів, які функціонують як знаки думок чи намірів. Ці відношення можна представити у вигляді схеми (рис. 2).

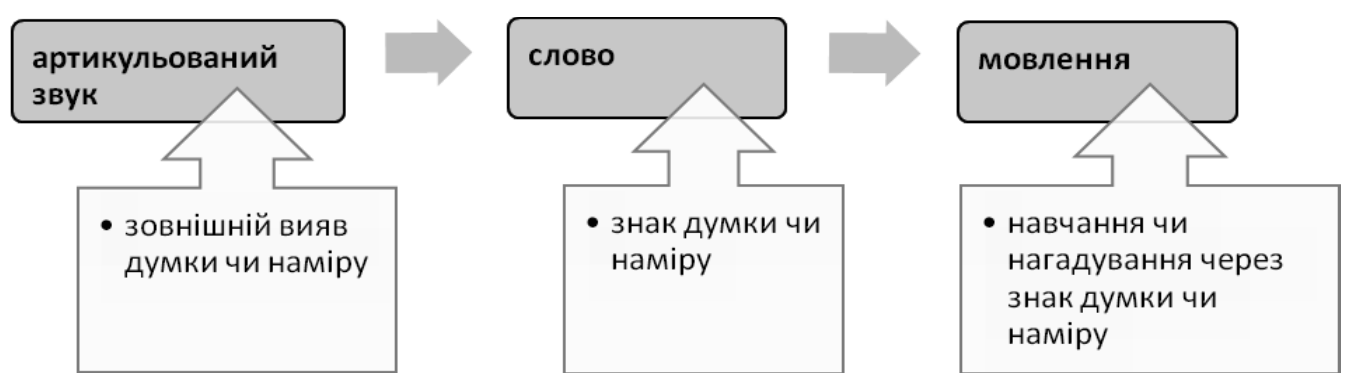

Рис. 2. Тлумачення мовлення в Августина.

Августин також додає, що можливе внутрішнє мовлення, коли ми не використовуємо звуки, а лише слова в розумі (speech within our minds). Таке мовлення $є$ пригадуванням тих речей (realities), для яких слова є знаками. Далі він формулює дуже важливе положення знакової теорії: “non esse signum nisi aliquid significet (only that can be a

1 Цей термін впровадив у філософію Франц Брентано (1838-1917) в останній чверті XIX століття, розвиваючи погляди схоластів. Він тлумачить інтенціональність як спрямованість ментальних феноменів на об'єкт, яку не слід розуміти як значення речі [20]. 
sign which signifies something)"- лише те, котре щось означує, може бути знаком. I далі включає ще одне дуже вагоме спостереження, яке поклало початок поділові знаків на мовні та немовні. Августин чітко вказує, що означники для одного й того самого означуваного можуть бути різними, наприклад, на предмет можна вказати словом і пальцем, історію можна розповісти словами і танцем ${ }^{1}$.

Докладне прочитання трактату засвідчує, що Августин усебічно розглядає, як відбувається означування, що підтверджує думку про створення семіотичної доктрини. Він аналізує різні випадки семіозису: 1) знаки означують через знаки, як-от, у випадку, коли в мовленні ми використовуємо слова для означування інших знаків, наприклад, вимовляючи “жест” чи “буква”, бо ці два слова означують знаки; 2) знаки означують не-знаки, наприклад, передаємо словом щось, що не є знаком, як-от “камінь”. Речі, які не $\epsilon$ знаками, він пропонує назвати "significables": Placetne appellemus significabilia ea quae signis significari possunt et signa non sunt, sicut ea quae videri possunt, visibilia nominamus, ut de his deinceps commodius disseramus? (Shall we call things which can be signified by signs but are not signs "significables", as we call things that can be visible) -Чи можемо ми називати означуваним те, що може означуватися знаками, але не $\epsilon$ ними, оскільки ми називаємо видимим те, що може бути побаченим? Не викликає сумніву, що Августин випередив Соссюра в тлумаченні означника та означуваного, й цілком слушним є переконання Е. Кошераю ${ }^{2}$, що в "De magistro" Августина й у Св. Томи Соссюр міг би знайти тоншу й глибшу теорію знака, ніж побудована ним [3, с. 152].

Окремо Августин розглядає оніми й вибудовує таке тлумачення їхнього семіозису: 'слово' $є$ знаком, що вказує на 'ім'я' (назва ріки), $\rightarrow$ 'ім'я' $є$ знаком, що вказує на 'ріку', $\rightarrow$ 'ріка' $є$ знаком речі, яку ми бачимо. Всі оніми є словами, однак не всі слова $є$ онімами, тобто оніми завжди означують інші знаки (перший $з$ описаних вище випадків семіозису). Августин намагається пояснити відмінність між verbum і nomen через етимологію: verbum розглядається як похідне від verberare “бити, вражати слух”, а nomen “ім'я” від noscere “знати”, отож, перше пов”язане зі слухом, а друге - з розумом. Погоджуюся з Ц. Тодоровим, що такі міркування $\epsilon$ псевдоетимологічними [9, с. 32].

Августин також розглядає такі випадки означування, коли знак вказує на інші речі й разом $з$ тим - на себе, як-от, “сполучник”, і такі, коли знаки взаємно означуються, як-от, nomen і onoma.

Коло семіотичних міркувань замикається, коли Августин переходить до епістемологічних тверджень і вказує, що означувані речі є важливіші, ніж їхні знаки:

1 Сьогодні дослідження різних модальностей чуттєвого сприйняття та потенціал їхньої трансформації з використанням засобів мовного коду є одним із напрямів дослідження у лінгвокультурній семіотиці.

2 Кошераю Еухеніо (1921-2002) - німецький учений-лінгвіст румунського походження. Фахівець у галузі романського мовознавства, автор понад 50 книг. Аналізуючи питання співвідношення мови й мовлення, діахронії та синхронії, Кошераю намагається подолати суперечності між традиційним мовознавством та структуралізмом. При цьому він нерідко використовує праці філософів, зокрема Св. Августина, розглядаючи питання філософії мови. 
"Concedo ipsam scientiam, quae per hoc signum evenit, eidem signo esse anteponendam I agree that the knowledge conveyed by the sign is more important than the sign itself)"; отож, не пізнання існує для знака, а знак для пізнання. І хоча знання ми поціновуємо більше ніж знаки, за допомогою яких ми його здобуваємо, все ж ми не можемо здобути його без знаків. Але самі знаки пізнаються через знання речей, які вони означують. Отож, у заключній частині трактату Августин формулює дуже важливе твердження його семіотичної доктрини: "per ea signa quae verba appellantur, nos nihil discere; potius enim, ut dixi, vim verbi, id est significationem quae latet in sono, re ipsa quae significatur cognita, discimus, quam illam tali significatione percipimus (We learn nothing by means of these signs wecall words. On the contrary, as I said, we learn the force of the word, that is, the meaning which lies in the sound of the word, when we come to know the object signified by the word. Then only do we perceive that the word was a sign conveying that meaning)". - Ми пізнаємо силу слова, тобто те значення, яке приховане у звучанні, коли знаємо об'єкт, який воно означує. I лише тоді ми розуміємо, що це слово $є$ знаком, який передає це значення.

$\mathrm{Bce}$, що ми сприймаємо, ми сприймаємо або органами чуттів, або розумом. Перше Августин називає sensibilia (sensible things) - речі, які сприймаються органами чуттів, а друге - intellegibilia (intelligible things) - речі, які осягаються розумом. Коли мова йде про речі, які зараз не представлені у відчуттях, але раніше були, то ми говоримо не про самі речі, а про образи, збережені в пам'яті. У семіотичній доктрині Ч. Пірса ця диференціація представлена розглядом двох типів об'єкта знака: динамічного (dynamical) та безпосереднього (immediate). Перший - це реальний об'єкт референції ('самі речі'), а другий - той, який представлений знаком (ментальний образ) (докладніше див. [10]).

На завершення Августин порушує питання істинності знання, отриманого за посередництвом знаків. Розуміння знаків передбачає розуміння того, що говорить мовець про речі, які вони позначають, але встановлювати істинність того, що каже вчитель, повинен сам учень. Знаки використовуються лише як особливі засоби, завдяки яким учень “вчиться внутрішньо". Єдиний правдивий учитель - це Отець Небесний, який дає це внутрішнє знання. Отже, Августин у трактаті "Про вчителя" не просто торкається, а докладно обгрунтовує тлумачення знака як співвідношення означника та означуваного, розглядає природу їхнього зв'язку та роль в передаванні знань.

Через 10 років після написання “De Magistro" Августин поглиблює вже сформовану семіотичну доктрину в трактаті “De Doctrina Christiana” . Цей твір складається з чотирьох книг. Перші три були написані в 397 році, а четверта додана у 426. Питання природи знака Августин розглядає у перших трьох книгах, i хоча цей розгляд представлено в контексті християнської філософії та богослов'я, його теорія $є$ чіткою та аргументованою. В другому розділі першої книги він розвиває твердження, яке вже звучало в трактаті "Про вчителя": “Omnis doctrina vel rerum est vel signorum, sed res per signa discuntur (All instruction is either about things or about signs; but things are learnt by means of signs")

Для аналізу використано латинський текст із уже згадуваного сайту Augustinus Hipponensis [14] та англійський переклад, опублікований цифровою бібліотекою The Christian Classics Ethereal Library, яка вже розмістила в Інтернеті сотні книг Християнської класики. Стосовно тексту Августина On Christian Doctrine [30], то, на жаль, не вказано імені перекладача. 
- Усі вчення є вченнями про речі або про знаки, але знаки є засобом вивчення речей. Августин висловлює думку, що є речі, які можуть бути лише речами (дерево), речі, які можуть бути знаками (дерево, яке Мойсей кинув у воду і вода зробилася солодкою), i знаки, які можуть бути лише знаками. Знаки він тлумачить як: “....res eas videlicet quae ad significandum aliquid adhibentur. Quamobrem omne signum etiam res aliqua est; quod enim nulla res est, omnino nihil est (those things, to wit, which are used to indicate something else. Accordingly, every sign is also a thing; for what is not a thing is nothing at all) - речi, які вказують розумові на щось інше. Відповідно, кожен знак - це річ, бо те, що не річ, те - ніщо. Тут Августин чітко формулює розуміння матеріальності знака.

Далі у першій книзі він тлумачить природу різних речей та труднощів інтерпретації Святого Письма. У пошуках шляхів подолання цих труднощів, Августин у другій книзі знову звертається до питання знаків і дає визначення, схоже на те, яке вже було сформовано в трактаті "Про діалектику": "Signum est enim res, praeter speciem quam ingerit sensibus, aliud aliquid ex se faciens in cogitationem venire (a sign is a thing which, over and above the impression it makes on the senses, causes something else to come into the mind as a consequence of itself) ". - Знак - це річ, яка окрім і через дію на відчуття викликає щось інше в розумі як наслідок цієї дії. Як-от, відбитки лап є знаком, що пройшла тварина, а дим - знаком вогню. Вагомим здобутком семіотики Августина $€$ розмежування природних та конвенційних знаків. Наведені вище приклади знаків він відносить до природних, а до конвенційних - ті, які люди використовують, щоб при спілкуванні обмінюватись ними для виявлення своїх думок. Августин наголошує при цьому, що вони повинні мати фізичну форму вияву і сприйматися органами слуху чи зору. Це можуть бути мовні знаки, але сюди він також відносить немовні, як-от, особливості одягу чи прикрас, які вказують на стать чи статус, та інші знаки, відсутність яких ускладнювала б або навіть унеможливлювала б спілкування. У цьому контексті Августин зазначає, що для означення певних речей в різних культурах можуть використовуватись різні знаки, наприклад, одиниці виміру.

У розділі 10 другої книги в контексті інтерпретації Святого Письма Августин пропонує ще один поділ конвенційних знаків: 'власне' знаки (propria) та 'переносні' знаки (translata). Перші вказують на об’єкти, для означення яких вони були створені, а другі - на речі, які вказують на щось інше. Так, коли ми кажемо bos, то розуміємо те, що позначає цей знак: вола. Зокрема, коли читаємо, що у законі Мойсея написано: “Не зав’язуй рота волові, як молотить” (див. український переклад першого послання Апостола Павла до коринтян [5, с. 210], то розуміємо, що йдеться про проповідника. Як віл має їсти, коли працює, так проповідник має отримувати підтримку за його служіння. Міркування про propria та translata та про роль знання мови в процесах інтерпретації фактично закладають основи сучасних поглядів на інформаційний та культурний виміри семіозису (докладніше див. [10]).

Цветан Тодоров, аналізуючи трактат “Про Християнську доктрину”, привертає увагу до того, що в цьому трактаті Августин поглиблює теорію знаків, оскільки зосереджується не лише на означуванні, а на комунікації: під дією знаків у розумі слухача виникає смисл, який є в розумі мовця, а продукувати знаки означає виявляти смисл назовні. Тодоров додатково аналізує розгортання схеми комунікації в трактатах 
“Катехизм для початківців”, “Про трійцю” та в 11-й книзі “Сповіді” [9, с. 33-36].

Висновки та перспективи подальших досліджень. Августин Аврелій найвидатніший християнський філософ, який належить до періоду пізньої античності, однак через його значущість для філософської традиції Середньовіччя він нерідко позиціонується як перший середньовічний філософ. Поділяємо думку Д. Кларка, який вважає ідеї Августина середньовічною “концепцією знака” [16, с. 19]. Августин розвиває цю концепцію в контексті розгортання його Християнської доктрини. Він не використовував терміна “семіотика" чи його похідних, однак його теоретичні засновки та оригінальність узагальнень становлять першу теорію в історії західної думки, яка заслуговує цієї назви. Отож, не погоджуюся з твердженнями, що, оскільки знаки не були для Августина окремою темою, то не можна говорити про нього як про творця теорії знаків [7, с. 7]. Августин Аврелій створює цілісну теорію, в якій пріоритетом $\epsilon$ розгляд мови як системи знаків. Його теорія значною мірою підпорядкована його зацікавленню Біблійними ‘знаками’, оскільки давала можливість тлумачити ‘буквальні' та 'переносні' смисли в Біблійному тексті i, таким чином, поглибила i, фактично, поглинула його герменевтику.

У досліджених трактатах Августина Аврелія: 1) дається чітке визначення знака; 2) встановлюється зв'язок означника з об'єктом означення та описується природа цього зв'язку (план означування); 3) тлумачиться зв'язок мовця й слухача при передаванні знань (план комунікації); 4) представлена диференціація знаків різної природи: мовних та немовних.

Отже, вектор семіотичних пошуків, заданий Августином, спрямований на виявлення зв'язку об'єктів, знаків і свідомості. Його теорія знаків входить у загальну теорію знання й цілком відповідає сучасним поглядам про те, що досягнення семіотики породжують нагромадження знань усередині багатьох окремих наук.

\section{СПИСОК ВИКОРИСТАНОЇ ЛІТЕРАТУРИ}

1. Кассен Б., Ідельфонс Ф., Кліппі К., Розьє-Каташ І. Означник/означене. Свропейський словник філософій: Лексикон неперекладностей [пер. 3 фр. Олексія Панича]. Том 4. Київ : ДУХ І ЛІТЕРА, 2016. С. 146-157.

2. Кондратишин I. Святий Августин про слово у навчанні та пізнанні. Наукові записки УКУ. 2015. Ч. 5 : Богослов'я, вип. 2. С. 164-178.

3. Косериу Э. Синхрония, диахрония, история. Новое в лингвистике. Выл. III [сост., ред. и вступ. статьи В. А. Звегинцева]. Москва : Изд-во иностр. лит-ры, 1963. С. 143-343.

4. Кремень В. Г., Ільїн В. В. Філософія: мислителі, ідеї, концепції : підручник. Київ : Книга, 2005. 528 с.

5. Новий завіт. Святе письмо Старого та Нового Завіту [пер. Івана Хоменка]. Львів : Видав. отців Василіян “Місіонер”, 2007. С. 1-321.

6. Святий Августин. Сповідь [пер. з латини Ю. Мушака]. Львів : Свічадо, 2008. 365 с.

7. Скрипник К. Д. К истории семиотических идей: три “знаковых” трактата Августина. Научные ведомости Белгородского государственного университета. Серия Философия. Сочиология. Право. 2011. № 8 (103). Вып.16. С. 5-12.

8. Содомора П. Поняття знака у контексті переходу від античної до середньовічної філософії (на матеріалі творів Томи з Аквіну). Грані. 2016. № 1 (129). С. 84-87. 
9. Тодоров Ц. Теории символа [пер. с франц. Б. Нарумова]. Москва : Дом интеллектуальной книги, Русское феноменологическое общество, 1998. 408 с.

10. Andreichuk N. The doctrine of semiosis: new tasks and challenges. Vectors of the development of philological sciences at the modern stage. Lviv-Torun : Liha-Pres, 2019. P. $1-20$.

11. Augustine of Hippo. On dialectics. URL: https://trialectics.net/theology-index/christianity/ theologians/augustine-of-hippo/.

12. Augustine St. The teacher (De Magistro). Augustine. Earlier Writings [ed. and trans. by J.H.S. Burleigh]. Louisville, London : Westminster John Knox, 1953. P. 64-101.

13. Augustinus Hipponensis. De Dialectica. URL: http://www.augustinus.it/latino/dialettica/ index $2 . \mathrm{htm}$.

14. Augustinus Hipponensis. URL: De Doctrina Christiana. URL:http://www.augustinus.it/ latino/dottrina cristiana/index2.htm.

15. Augustinus Hipponensis. De Magistro. URL: http://www.augustinus.it/latino/maestro/ index.htm.

16. Clarke D. S., Jr. Principles of Semiotics. London and New York: Routledge \& Kegan Paul, 1987. $164 \mathrm{p}$.

17. Connaghan Ch. Signs, language and knowledge in St. Augustine's DE MAGISTRO. URL: https://discovery.ucl.ac.uk/id/eprint/1445358/.

18. Deely J. Augustine and Poinsot. The Protosemiotic Development. Scranton : Univ. of Scranton Press, 2009. 200 p.

19. Eco U. Semiotics and the Philosophy of Language. Bloomington : Indiana Univ. Press.1984. $242 \mathrm{p}$.

20. Huemer W. Franz Brentano. The Stanford Encyclopedia of Philosophy [Spring 2019 Edition, E. N. Zalta (ed.)]. URL: https: //plato.stanford.edu/archives/spr2019/entries/brentano/.

21. Jackson B. D. The theory of signs in St. Augustine's De doctrina christiana. Revue des études augustiniennes. 1969. Vol. 15. P. 9-49.

22. Jacob P. Intentionality. The Stanford Encyclopedia of Philosophy [Winter 2019 Edition, E. N. Zalta (ed.)]. URL: https://plato.stanford.edu/archives/win2019/entries/intentionality/.

23. Kuypers K. Der Zeichen- und Wortbegriff im denken Augustins. Amsterdam : N. V. Swets \& Zeitlinger, 1934. 99 p.

24. Markus R. A. St. Augustine on signs. Phronesis. 1957. 2 (1). P. 60-83.

25. Nöth W. Handbook of Semiotics. Bloomington : Indiana Univ. Press, 1995. 576 p.

26. PeirceCh. How to make our ideas clear. Peirce on Signs. Writings on Semiotic by Charles Sanders Peirce [ed. by James Hoopes]. Chapel Hill and London : Univ. of North Carolina Press, 1991. P. 160-179.

27. Peirce Ch. Semiosis. Commens Dictionary. URL: http://www.commens.org/dictionary/ term/semiosis.

28. Peirce Ch. Sign. Commens Dictionary. URL: http://www.commens.org/dictionary/term/ sign.

29. Ruef H. Augustin über Semiotik und Sprache. Sprachtheoretische Analysen zu Augustins Schrift 'De Dialectica', mit einer deutschen Uebersetzung. Bern : Wyss Verlag, 1981. Vol. 1. $230 \mathrm{p}$.

30. St. Augustine. On Christian Doctrine. Christian Classics Ethereal Library. URL: http:// www.ccel.org/ccel/augustine/doctrine.html.

31. Todorov Tz. Theories of the Symbol. Ithaca : Cornell Univ. Press. 1982. 302 p. 


\section{REFERENCES}

1. Kassen B., Idelfons F., Klippi K., Rozye-Katash I. Oznachnyk/oznachene [Signifier and signified]. Yevropeiskyi slovnyk filosofii: Leksykon neperekladnostei [European Dictionary of Philopsophy: Lexicon of Non-Translatable] [per. z fr. Oleksiya Panycha]. Vol. 4. Kyiv : DUKH I LITERA, 2016. S. 146-157.

2. Kondratyshyn I. Svyatyi Avhustyn pro slovo u navchanni ta piznanni [St. Augustine about the word in learning and cognition]. Naukovi zapysky UKU. 2015. Ch. 5: Bogoslovya, vyp. 2. S. 164-178.

3. Koseriu E. Synkhroniia, diakhoniia, istoriia [Syncrony, diachrony, and history]. Novoie $v$ lingvistike [New in Linguistics]. Vyp. III [sost., red. i vstup. statia V. A. Zvehintseva]. Moskva : Izd-vo inostr. lit-ry, 1963. S. 143-343.

4. Kremen V. H., Ilyin V. V. Filosofiia: myslyteli, ideyi, kontseptsiyi: Pidruchnyk [Philosophy: Thinkers, Ideas, and Concepts: Textbook]. Kyiv : Knyha, 2005. 528 s.

5. Novyi zavit. Sviate pysmo Staroho ta Novoho Zavitu [Holy Scripture of the Old and New Testaments] [per. Ivana Khomenka]. Lviv : Vydav. ottsiv Vasyliyan "Misioner", 2007. S. $1-321$.

6. Sviatyi Avhustyn. Spovid [Confession] [per. z latyny Yu. Mushaka]. Lviv : Svichado, 2008. $365 \mathrm{~s}$.

7. Skrypnyk K. D. K istorii semioticheskikh idey: tri "znakovykh" traktata Avgustina [Towards the history of semiotic theories: three "sign" treaties of Augustine]. Nauchnyie vedomosti Belgorodskoho gosudarstvennogo universiteta. Seriia Filisofia. Sotsiologiia. Pravo. 2011. № 8 (103). Vyp. 16. S. 5-12.

8. Sodomora P. Poniattia znaka u konteksti perekhodu vid antychnoi do seredniovichnoi filosofii (na materiali tvoriv Tomy z Akvinu) [The notion of sign in the context of transition from ancient to medieval philosophy]. Grani. 2016. № 1(129). S. 84-87.

9. Todorov Ts. Teorii simvola [The Theories of the Symbol] [per. s frants. B. Narumova]. M.: Dom intelektualnoi knigi, Ruskoie fenomenologicheskoie obshchestvo, 1998. $408 \mathrm{~s}$.

10. Andreichuk N. The doctrine of semiosis: new tasks and challenges. Vectors of the development of philological sciences at themodern stage. Lviv-Torun : Liha-Pres, 2019. P. $1-20$.

11. Augustine of Hippo. On dialectics. URL: https://trialectics.net/theology-index/christianity/ theologians/augustine-of-hippo/.

12. Augustine St. The teacher (De Magistro). Augustine. Earlier Writings [ed. and trans. by J.H.S. Burleigh]. Loouisville, London : Westminster John Knox, 1953. P. 64-101.

13. Augustinus Hipponensis. De Dialectica. URL: http://www.augustinus.it/latino/dialettica/ index $2 . \mathrm{htm}$.

14. Augustinus Hipponensis. URL: De Doctrina Christiana. URL: http://www.augustinus.it/ latino/dottrina_cristiana/index2.htm.

15. Augustinus Hipponensis. De Magistro. URL: http://www.augustinus.it/latino/maestro/ index.htm.

16. Clarke D. S., Jr. Principles of Semiotics. London and New York : Routledge \& Kegan Paul, 1987. $164 \mathrm{p}$.

17. Connaghan Ch. Signs, language and knowledge in St. Augustine's DE MAGISTRO. URL: https://discovery.ucl.ac.uk/id/eprint/1445358/.

18. Deely J. Augustine and Poinsot. The Protosemiotic Development. Univ. of Scranton Press, 2009. $200 \mathrm{p}$.

19. Eco U. Semiotics and the Philosophy of Language. Bloomington : Indiana Univ. Press. 1984. 242 p. 
20. Huemer W. Franz Brentano. The Stanford Encyclopedia of Philosophy [Spring 2019 Edition, E. N. Zalta (ed.)]. URL: https://plato.stanford.edu/archives/spr2019/entries/brentano/.

21. Jackson B. D. The theory of signs in St. Augustine's De doctrina christiana. Revue des études augustiniennes. 1969. Vol. 15. P.9-49.

22. Jacob P. Intentionality. The Stanford Encyclopedia of Philosophy [Winter 2019 Edition, E. N. Zalta (ed.)]. URL: https://plato.stanford.edu/archives/win2019/entries/intentionality/.

23. Kuypers K. Der Zeichen- und Wortbegriff im denken Augustins. Amsterdam : N. V. Swets \& Zeitlinger, 1934. 99 p.

24. Markus R. A. St. Augustine on Signs. Phronesis. 1957. 2 (1). P. 60-83.

25. Nöth W. Handbook of Semiotics. Bloomington: Indiana Univ. Press, 1995. 576 p.

26. PeirceCh. How to make our ideas clear. Peirce on Signs. Writings on Semiotic by Charles Sanders Peirce [ed. by James Hoopes]. Chapel Hill and London : Univ. of North Carolina Press, 1991. P. 160-179.

27. Peirce Ch. Semiosis. Commens Dictionary. URL: http://www.commens.org/dictionary/ term/semiosis.

28. Peirce Ch. Sign. Commens Dictionary. URL: http://www.commens.org/dictionary/term/ sign.

29. Ruef H. Augustin über Semiotik und Sprache. Sprachtheoretische Analysen zu Augustins Schrift 'De Dialectica', mit einer deutschen Uebersetzung. Bern : Wyss Verlag, 1981. Vol. 1. $230 \mathrm{p}$.

30. St. Augustine. On Christian Doctrine. Christian Classics Ethereal Library. URL: http:// www.ccel.org/ccel/augustine/doctrine.html.

31. Todorov Tz. Theories of the Symbol. Ithaca : Cornell Univ. Press. 1982. 302 p.

Стаття надійшла до редколегії 28.02.2020

Прийнята до друку 03.04.2020

\title{
DISCOURSE ON SIGNS IN ST. AUGUSTINE'S TREATISES: ANCILLARY CONSIDERATIONS OR A FULL-FLEDGED THEORY?
}

\author{
Nadiya Andreichuk
}

\author{
Ivan Franko National University of Lviv, \\ 1, Universytetska Str., Lviv, Ukraine, 79000 \\ nadiya.andreychuk@lnu.edu.ua
}

\begin{abstract}
The author contends that the history of semiotics cannot be conceived of without Augustine's landmark contribution. The article presents a theoretical investigation of the issue of sign as discussed by Aurelius Augustinus, bishop of Hippo (354-430 A.D.), also known as Augustine or St. Augustine. The author tries to provide evidence that Augustine's speculations on the nature of signs deserve the name of the first semiotic theory. The article offers the results of the author's analysis of the texts of three treatises touching upon the issue of sign, namely, De Dialectica, De Magistro and De Doctrina Christiana, as these three opuscula present the core of Augustine's insights into signs. It is shown that St. Augustine applied the term "sign" to define something which presents itself to the senses and something other than itself to the mind, thus suggesting the 'classical' definition, which since then has been acknowledged by all semiotic doctrines. Following the
\end{abstract}


Augustine's line of thought, the author has sought to look at his theory of language conceived in terms of a theory of signs which reflected the primacy of Augustine's interest in the acquisition of knowledge and analysis of Scriptural 'signs'. Basic ideas of Augustine's doctrine are discussed and the generalized representation of sign relations is suggested, namely, the nature of the relation between words and things that they signify, between speaker and hearer, and between signs of different types.

The author comes to the conclusion that Augustin's in-depth analysis of signs and their importance in gaining knowledge proves that he was one of the first thinkers who provided a systematic study of signs and deserves to be remembered not only in the history of Christianity but in the history of Western thought for his achievements in semiotics.

Key words:Aurelius Augustinus, sign, lingual sign, speech, knowledge. 